\title{
Muir-Torre Syndrome - Treatment with Isotretinoin and Interferon Alpha-2a Can Prevent Tumour Development
}

\author{
Tim Graefe $^{a} \quad$ Uwe Wollina $^{a}$ Hans-Joachim Schulz ${ }^{b}$ Walter Burgdorf ${ }^{c}$ \\ a Department of Dermatology and Allergology, Friedrich Schiller University of Jena, bInstitute for Clinical Pathology \\ and Cytology, Eisenach, and 'Department of Dermatology, Ludwig Maximilians University, Munich, Germany
}

\section{Key Words}

Muir-Torre syndrome - Tumour

syndromes $\cdot$ Interferon $\cdot$ Retinoids

\begin{abstract}
Muir-Torre syndrome is a genodermatosis in which multiple internal malignancies are associated with cutaneous sebaceous tumours and kerato-acanthomas. A 57-yearold man presented with multiple sebaceous tumours, kerato-acanthomas, verrucous carcinoma of the nose, renal cell and transitional cell carcinomas of the left kidney, adenoma of the colon and a positive family history of colon carcinoma. He was treated with interferon (IFN- $\alpha 2 a$ ) s.c. $3 \times 10^{6}$ $U$ three times a week along with $50 \mathrm{mg}$ isotretinoin daily as well as topical isotretinoin gel. During a follow-up of 29 months, only 1 sebaceous skin tumour developed and was removed, whereas more than 30 such skin tumours had been surgically removed during the last 3 years. No evidence of internal tumour development or recurrence was found. The combination of IFN with retinoids seems to be of promise to prevent tumour development in Muir-Torre syndrome.
\end{abstract}

Copyright $(\subset 2000$ S. Karger AG, Basel
Since Muir et al. [1] in 1967 published a case of multiple carcinomas of the bowel and larynx in association with sebaceous adenoma and kerato-acanthoma, more than 150 patients have been described with a MuirTorre syndrome (MTS) [2]. The MTS is an autosomal-dominant one closely related to the cancer family syndrome.

In an analysis of 147 published cases of MTS, 292 visceral cancers were found; about one half were colorectal carcinomas and $20 \%$ involved the genitourinary tract [3]. Both early detection and curative treatment of the internal malignancies are challenging. There is no established prophylactic regimen. We report on a patient with definite MTS in whom preventive therapy appeared successful.

\section{Case Report}

A 57-year-old man was admitted to our hospital in March 1997, with a 12-year history of cutaneous and internal tumours. Twelve cutaneous tumours up to $2 \mathrm{~cm}$ in diameter were removed from 1985 to 1987 ; histology reports are not available.

In 1995, another 10 cutaneous tumours were excised; they showed varying degrees of sebaceous differentiation or were keratoacanthomas. In 1996, 2 carcinomas of the left kidney (renal cell carcinoma, transitional cell carcinoma of renal pelvis) led to nephrectomy. Three further cutaneous sebaceous tumours were removed.
The family history disclosed that the patient's brother died due to a metastatic colon cancer.

On examination the patient showed multiple yellowish or skin-coloured facial papules. On the neck, shoulder and back multiple mostly cystic tumours and livid scars from surgery were present (fig. 1a, b, 2a). A subcutaneous tumour on the right upper arm was enucleated; it was a large cystic sebaceoma. Additionally a verrucous carcinoma of the nose and a tubular adenoma of the colon were removed. The verrucous carcinoma revealed epidermal findings resembling a wart, i.e. compact hyperkeratosis, focal parakeratosis and acanthosis. Furthermore, the typical findings of pleomorphic keratinocytes, mitotic figures and dyskeratotic cells led to the diagnosis of a verrucous carcinoma. Histologic findings of some of his sebaceous tumours have already been described by Rütten et al. [4; case 7]. The routine laboratory examinations were normal as were chest $\mathrm{X}$-ray and double contrast X-ray of the small intestine. Oesophagogastroduodenoscopy showed no tumour but an oesophagitis due to hiatus hernia. Cystoscopy was normal. A prostatitis was found.

The diagnosis of MTS was established according to accepted criteria [2,3]. As an attempt to prevent further tumour development, we prescribed isotretinoin (Roaccu$\tan ^{\circledR}$ ) $50 \mathrm{mg} /$ day and interferon $\alpha 2 \mathrm{a}$ (IFN$\alpha 2 \mathrm{a}$, Roferon $\left.{ }^{\circledR}\right)$ s.c. $3 \times 10^{6} \mathrm{U}$ three times a week. Topical isotretinoin gel (Isotrex ${ }^{\circledR}$ ) completed our regimen. The facial sebaceous

\section{KARGER \\ Fax +4161306 1234 \\ E-Mail karger@karger.ch} www.karger.com (c) 2000 S. Karger AG, Basel

1018-8665/00/2004-0331\$17.50/0

Accessible online at: www. karger.com/journals/drm

\author{
U. Wollina \\ Department of Dermatology, Friedrich Schiller University of Jena \\ Erfurter Strasse 35 \\ D-07740 Jena (Germany) \\ Fax+49 36419374 16, E-Mail uwol@derma.uni-jena.de
}



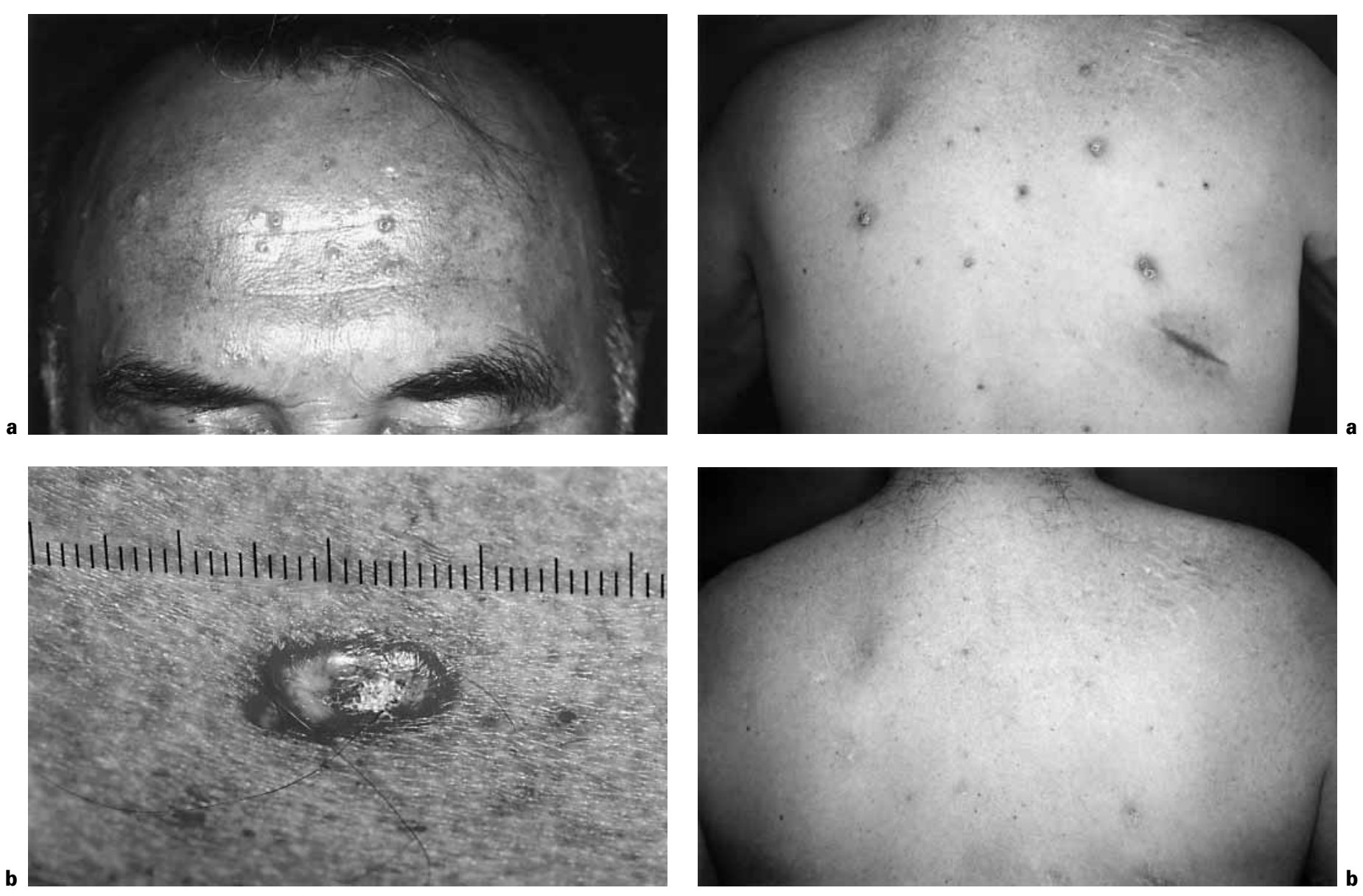

Fig. 1. Clinical presentation of skin manifestations of MTS. a Multiple sebaceous hyperplasias on the forehead. b Sebaceoma.

Fig. 2. MTS - clinical course during treatment with interferon $\alpha 2 \mathrm{a}$ and retinoids. a Before treatment, multiple tumours on the back. b After 3 months of treatment, the tumours had disappeared.

hyperplasias, i.e. a hair follicle and one or several enlarged sebaceous glands with sharp circumscription and a symmetric shape as well as other remaining cutaneous tumours disappeared after 3 months (fig. 2a, b). We reduced the daily isotretinoin dosage to 30 mg. Within the next 9 months only 1 cystic skin tumour developed. There has been no evidence of further progression including internal tumour development. The treatment has been well tolerated with no severe sideeffects noted. Blood and urine examinations remained normal.

\section{Discussion}

MTS is an autosomal-dominant inherited trait with an increased risk of internal cancer and a wide range of sebaceous neoplasms and kerato-acanthomas [1-3]. In our patient, we have found the deep cystic sebaceous tumours which are particularly suggestive of MTS $[4,5]$.

A striking change in tumour tissues is a genomic replication error known as microsatellite instability (MSI) caused by alterations in at least 1 of 4 DNA mismatch repair genes. MSI has been found frequently in germline mutations of the mismatch repair genes hMSH2 and hMLH1. MTS patients exhibit significantly more mutations in the $\mathrm{hMSH} 2$ gene than in the hMSH1 gene [6-9]. In addition a loss of heterozygosity has been detected at D2S119, a marker located in the vicinity of hMSH2. Proliferating cystic sebaceous tumours show a frameshift mutation in exon 2 of the DNA mismatch repair gene hMLH1(150insT) [4, 8]. Patients with MSI form a subgroup of MTS with early onset of colorectal cancer, prolonged survival following diagnosis of visceral malignancy and a greater number of visceral and skin tumours [6, 7, 9-11].

The case presented here fulfilled the accepted criteria for a diagnosis of MTS. He had numerous sebaceous skin tumours, kerato-acanthomas, adenoma of the colon, genitourinary cancer, verrucous cancer of the nose and a positive family history for colorectal cancer. From the clinical presentation this case is exceptional since two different tumours were found in his left kidney - a renal cell carcinoma and a transitional cell carcinoma [1-3]. In a recent survey on 205 patients with MTS only 12 had tumours of the kidney (1 hypernephroma, 11 renal pelvis tumours) [12].

While once a tumour is identified, it must be treated by standard methods, usually surgical ones, the clinical challenge is prophylaxis. The most rational target for cancer prevention is minimal cellular deviations 
seen in early phases of carcinogenesis. IFNs are useful candidates for prophylaxis after surgical or radiosurgical removal of malignant tumours. IFN- $\alpha$ is widely used in adjuvant therapy protocols in melanoma, nonmelanoma skin cancer and urogenital cancer among others. The mechanisms may involve the induction of apoptosis, as well as antiproliferative and immunomodulating effects [13]. Preclinical and clinical studies suggest synergistic antiproliferative and differentiating effects in selected solid tumours [14].

\section{References}

1 Muir EG, Yates Bell AJ, Barlow KA: Multiple primary carcinomata of colon, duodenum and larynx associated with keratoakanthoma of the face. Br J Surg 1967;54:191-195.

2 Schwartz RA, Torre DP: The Muir-Torre syndrome: A 25-year retrospect. J Am Acad Dermatol 1995;33:90-104.

3 Cohen PR, Kohn SR, Kurzrock R: Association of sebaceous gland tumors and internal malignancy: The Muir-Torre syndrome. Am J Med 1991;90:606-613.

4 Rütten A, Burgdorf W, Hügel H, Kutzner H, Hosseiny-Malayeri HR, Friedl W, Propping R, Kruse R: Cystic sebaceous tumors as marker lesions for the Muir-Torre syndrome: A histopathologic and molecular genetic study. Am J Dermatopathol 1999;21:405-413.

5 Burgdorf WH, Pitha J, Fahmy A: Muir-Torre syndrome: Histologic spectrum of sebaceous proliferations. Am J Dermatopathol 1986;8: 202-208.

6 Kruse R, Rütten A, Lamberti C, Hosseiny-Malayeri HR, Wang Y, Ruelfs C, Jungck M, Mathiak M, Ruzicka T, Hartschuh W, Bisceglia M, Friedl W, Propping P: Muir-Torre phenotype has a frequency of DNA mismatch-repairgene mutations similar to that in hereditary nonpolyposis colorectal cancer families defined by the Amsterdam criteria. Am J Hum Genet 1998;63:63-70.
Retinoids have occasionally helped in sebaceous proliferations and tumours and in multiple kerato-acanthomas. Isotretinoin has also been used in some patients with the MTS [15-17]. Retinoids have been shown to induce apoptosis in several cell types [18].

During the combined treatment with isotretinoin, IFN- $\alpha 2 \mathrm{a}$ and topical isotretinoin gel, only 1 cystic skin tumour developed during 29 months (after 9 months). There has been no evidence of new internal tumour development. The treatment has been well tolerated without severe side-effects.

Our conclusions are preliminary. However, the obvious improvement of pre-existing skin tumours and the prophylaxis of skin tumour development during combined treatment with IFN- $\alpha 2 \mathrm{a}$ and isotretinoin is remarkable. Further studies including prospective trials will show whether the effect is long lasting and helps prevent internal carcinomas.
7 Kruse R, Lamberti C, Wang Y, Ruelfs C, Bruns A, Esche C, Lehmann P, Ruzicka T, Rütten A, Friedl W, Propping P: Is the mismatch repair deficient type of Muir-Torre syndrome confined to mutations in the hMSH2 gene? Hum Genet 1996;98:747-750.

8 Kruse R, Rütten A, Hosseiny-Malayeri HR, Günzl H-J, Friedl W, Propping P: A novel germline mutation in the hMLH1 DNA mismatch repair gene in a patient with an isolated cystic sebaceous tumor. J Invest Dermatol 1999;112:117-118.

9 Honchel R, Halling KC, Schaid DJ, Pittelkow M, Thibodeau SN: Microsatellite instability in Muir-Torre syndrome. Cancer Res 1994;54: 1159-1163.

10 Peris K, Onorati MT, Keller G, Magrini F, Donati P, Muscardin L, Hofler H, Chimenti S: Widespread microsatellite instability in sebaceous tumours of patients with the Muir-Torre syndrome. Br J Dermatol 1997;137:356-360.

11 Akhtar S, Oza KK, Khan, SA, Wright J: MuirTorre syndrome: Case report of a patient with concurrent jejunal and uretral cancer and a review of the literature. J Am Acad Dermatol 1999;41:681-686.
12 Buechner SA, Wernli M, Harr T, Hahn S, Itin P, Erb P: Regression of basal cell carcinoma by intralesional interferon-alpha treatment is mediated by CD95 (Apo-1/ Fas)-CD95 ligand induced suicide. J Clin Invest 1997;199:26912696.

13 Gordon KB, Roenigk HH, Gendleman M: Treatment of multiple lesions of Bowen disease with isotretinoin and interferon alfa: Efficacy of combination chemotherapy. Arch Dermatol 1997;133:691-693.

14 Shaw JC, White CR Jr: Treatment of multiple keratoacanthomas with oral isotretinoin. J Am Acad Dermatol 1986;15:1079-1082.

15 Spielvogel RL, DeVillez RL, Roberts LC: Oral isotretinoin therapy for familial Muir-Torre syndrome. J Am Acad Dermatol 1985;12:475480.

16 Marcusson JA, Bjarnasson B, Bos AM: Isotretinoin for sebaceous skin lesions in Muir-Torre syndrome: A case report. Acta Derm Venereol 1998;78:479-480.

17 Hsu M-C: Systemic treatment of neoplastic conditions with retinoids. J Am Acad Dermatol 1998;39:108-113.

18 Evans TR, Kaye SB: Retinoids: Present role and future potential. Br J Cancer 1999;80:1-8. 